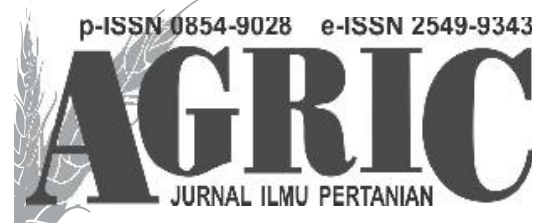

Fakultas Pertanian dan Bisnis Universitas Kristen Satya Wacana

Jl. Diponegoro 52-60 SALATIGA 50711 - Telp. 0298-321212 ext 354

email: jurnal.agric@adm.uksw.edu,website: ejournal.uksw.edu/agric

Terakreditasi Kementrian Riset, Teknologi dan Pendidikan Tinggi berdasarkan SK No 21/E/KPT/2018

\title{
PENGARUH VARIASI SUMBER CAHAYA LED TERHADAPPERTUMBUHAN DAN HASIL TANAMAN SELADA (Lactuca sativa var. Crispa L) DENGAN SISTEM BUDIDAYA HIDROPONIK RAKIT APUNG
}

\section{EFFECT OF LED LIGHT SOURCE VARIATION TOWARD CURLY LETTUCE (Lactuca sativa var. Crispa L) GROWTH AND YIELD IN HYDROPONIC RAFT SYSTEM}

\author{
Antonius Novinanto ${ }^{1}$ dan Andree Wijaya Setiawan ${ }^{2}$ \\ ${ }^{12}$ Program Studi Agroteknologi, Fakultas Pertanian dan Bisnis, Universitas Kristen Satya Wacana, \\ J1. Diponegoro 52-60 Salatiga - Indonesia 5071 \\ e-mail:512015003@student.uksw.edu; mawsetiawan@gmail.com
}

Diterima: 2 November 2019, disetujui, 13 Desember 2019

\begin{abstract}
In conventional curly lettuce cultivation there are several obstacles such as altitude, temperature, humidity, nutrient availability and light intensity that caused lettuce can not grow optimally. Indoor cultivation is one way to overcome problems that occurred in conventional cultivation, one of which is the intensity of light that is not suitable for the growth of lettuce plants. This study aims to determine the optimal LED electrical power and the effect of white LED lights and grow light on growth of lettuce plants with floating raft hydroponic cultivation system. This research has been carried out at Satya Wacana Christian University's Faculty of Agriculture and Business seed laboratory. The study used a randomized block design with six treatments: 100 watt grow light; 200 watt grow light; 300 watt grow light; 100 watt white light; 200 watt white light; 300 watt white light, which will be repeated four times. Parameters to be measured include the number of leaves, canopy diameter, crown wet weight, root wet weight, chlorophyll b, total chlorophyll and leaf area. Light intensity treatment carried out with a box with a size of $1 x 1 \mathrm{~m}$ placed in a dark room. The results showed that the 300 watt grow light treatment gave the best results, with canopy diameter $(45.10 \mathrm{~cm})$, number of leaves (18.25 strands), canopy wet weight $(225,967 \mathrm{~g})$, heavy dry canopy weight $(9.90 \mathrm{~g})$, canopy dry weight $(4.75 \mathrm{~g})$, and leaf area 6195,378 ( $\mathrm{mm})$.
\end{abstract}

Keywords: curly lettuce, light intensity, light source, light color, LED. 


\begin{abstract}
ABSTRAK
Dalam budidaya selada kriting secara konvensional terdapat beberapa kendala seperti ketinggian tempat, suhu, kelembapan, ketersediaan unsur hara dan intesitas cahaya sehingga menyebabkan pertumbuhan tanaman selada tidak dapat tumbuh maksimal. Budidaya indoor merupakan salah satu cara untuk mengatasi permasalahan di lahan salah satunya intensitas cahaya yang tidak mencukupi untuk pertumbuhan pertumbuhan tanaman selada. Penelitian ini bertujuan untuk, mengetahui daya lampu LED yang optimal dan pengaruh penggunaan lampu LED cahaya putih dan grow light terhadap pertumbuhan tanaman selada dengan sistem budidaya hidroponik rakit apung. Penelitian ini telah dilakukan di laboratorium benih Fakultas Pertanian dan Bisnis Universitas Kristen Satya Wacana. Rancangan yang digunakan RAK (Rancangan Acak Lengkap) dengan enam perlakuan: 100 watt grow light; 200 watt grow light; 300 watt grow light; 100 watt cahaya putih; 200 watt cahaya putih; 300 watt cahaya putih, yang akan diulang sebanyak empat kali. Parameter yang diamati meliputi jumlah daun, diameter tajuk, berat berangkasan basah tajuk, berat berangkasan basah akar, klofil a, klofil b, total klorofil dan luas daun. Perlakuan intesitas cahaya yang dilakukan dengan kotak dengan ukuran 1x1 m ditempatkan dalam ruang gelap. Hasil penelitian menunjukan bahwa pelakuan 300 watt grow light memberikan hasil terbaik, dengan diameter tajuk $(45,10 \mathrm{~cm})$, jumlah daun $(18,25$ helai), berat berangkasan basah tajuk $(225,967 \mathrm{~g})$, berat berat berangkasan kering tajuk $(9,90 \mathrm{~g})$, berat berangkasan kering tajuk $(4,75 \mathrm{~g})$, dan luas daun 6195,378(mm).
\end{abstract}

Kata kunci : selada keriting, intensitas cahaya, sumber cahaya, warna cahaya, LED.

\section{PENDAHULUAN}

Selada merupakan salah satu jenis sayuran yang banyak digemari oleh masyarakat. Tanaman selada memiliki tingkat nilai gizi tinggi dimana, dalam $100 \mathrm{~g}$ daun selada memiliki kandungan kalori sebesar 15,00 kal, protein mencapai 1,20 g, lemak 0,2 g, karbohidrat sebasar 2,9 g, Ca 22,00 g, P 25 mg, Fe 0,5 mg, Vitamin A 540 SI, Vitamin B 0,04 mg dan air sebanyak 94,80 g (Komala, 2017).

Selada pada umunya dimakan mentah sebagai lalapan dan dapat juga dibuat sabagai salad sayur. Selada memiliki peluang pasar yang cukup besar, baik untuk memenuhi kebutuhan pasar domestik maupun pasar internasional. Permintaan selada terus meningkat, dimana pada tahun 2012 permintaan selada di Indonesia mencapai 2.792 ton, sementara produksi dalam negeri tidak dapat memenuhi kebutuhan selada yang di butuhkan, sehingga di lakukan impor selada pada sebesar 145 ton (Badan Pusat Statistik, 2012). Permintaan, selada yang cukup tinggi menjadikan sayuran selada keriting memiliki nilai ekonomi yang cukup tinggi pula.

Dalam budidaya tanaman selada secara konvensional, terdapat beberapa kendala seperti keterbatasan lahan. Beralihnya fungsi lahan pertanian menjadi bangunan perumahan dan perkatoran menyebabkan penurunan lahan pertanian setiap tahunnya. Badan Pusat Statistik (2018) menyebut luas lahan pertanian mengalami penurunan. Pada tahun 2017 lahan pertanian seluas 7,75 juta hektar pada tahun 2018 mengalami penurunan sebesar 0,65 juta hektar dimana pada tahun 2018 lahan pertanian hanya mencapai luasan 7,1 juta hektar. Sehingga dilakukan budidaya tanaman secara indoor. Budidaya tanaman secara indoor terdapat 
kendala yaitu kurangnya intesitas cahaya yang menyebabkan tanaman tidak dapat tumbuh dengan optimal. Dalam budidaya tanaman intensitas cahaya merupak faktor penting untuk terpenting dalam proses pertumbuhan tanaman. Dimana cahaya berperan penting dalam berlangsungnya proses fotosintesis pada tanaman (Syafriyudin, 2015).

Untuk memenuhi kebutuhan intesitas cahaya, dapat dilakukaan dengan pemberian intesitas cahaya yang bersumber dari lampu LED. Keuntungan penggunaan lampu LED diantaranya memiliki spektrum cahaya yang kecil, konsumsi daya listrik yang lebih rendah dibandingkan dengan lampu neon dan lampu pijar, serta panas yang dihasilkan dari lampu LED lebih rendah dibandingkan dengan jenis lampu yang lain (Restiani et al, 2015). Tidak semua warna cahaya dapat diserap oleh tanaman. Warna cahaya yang diserap oleh tanaman yaitu cahaya merah dan biru, dimana cahaya merah dan biru baik untuk pertumbuhan tanaman, karena klorofil menyerap cahaya merah dan biru sehingga fotosintesis dapat berjalan secara optimal. Berdasarkan penelitian Sugara (2012) di Amazing Farm Lembang, penerapan teknologi dengan penambahan penyinaran lampu LED dengan sistem budidaya aeroponik pada tanaman selada dapat meningkatkan pertumbuhan dan hasil tanaman selada.

Tanaman selada dapat tumbuh dengan optimal dengan tercukupinya intensitas cahaya dan kualitas cahaya yang dibutuhkan oleh tanaman. Untuk memcukupi kebutuhan intensitas dan kualitas warna cahaya yang dibutuhkan oleh tanaman dapat digunakan lampu LED. Dimana lampu LED cukup rendah dalam konsumsi listrik. Namun belum diketahui daya lampu LED dan warna cahaya yang sesuai untuk pertumbuhan tanaman. Oleh karena itu penelitian ini dilakuan untuk mengetahui daya lampu LED dan warna cahaya yang baik untuk pertumbuhan tanaman.

\section{METODE PENELITIAN}

Penelitian ini telah dilakukan di laboratorium benih Fakultas Pertanian dan Bisnis Universitas Kristen Satya Wacana. Penelitian telah dilaksanakan pada bulan April hingga bulan Agustus 2019. Rancangan yang digunakan dalam penelitian ini adalah Rancangan Acak Kelompok (RAK) dengan enam perlakuan dan masing-masing diulang sebanyak empat kali. Perlakuan yang akan digunakan dalam penelitian ini berupa, warna cahaya dan tingkat intesitas cahaya yang dibagi menjadi enam perlakuan yaitu perlakuan sumber cahaya lampu LED grow light 100 watt, LED grow light 200 watt, LED grow light 300 watt, LED warna putih 100 watt, LED warna putih 200 watt, LED warna putih 300 watt.

Parameter yang dimati meliputi jumlah daun yang diukur tiga hari sekali dengan cara dihitung jumlah daun yang membuka sempurna, diameter tajuk diukur tiga hari sekali pada diameter terlebar, berat berangkasan basah tajuk dan berat berangkasan akar dengan metode gravimetric merupakan penimbangan dengan sifat pemurnian, dengan cara mengoven selama 48 jam dengan suhu $40^{\circ} \mathrm{C}$ sampai dengan berat konstan, total klorofil dengan metode spektrofotometri dengan bahan pelarut DSMO merupan pelarut organik polar yang lebih efektif dari pada pelarut yang lain 
(Limantara dan Heriyanto 2010) -dan luas daun dengan menggunakan software iDaun dengan cara mendigitasi pada tepi daun . Data hasil pengujian kemudian dianalisis dengan analisis sidik ragam satu arah (One Way Analysis of Varians) menggunakan program SAS 9.2. Uji posterior Beda Nyata Jujur (BNJ) kepercayaan 95\% dilakukan untuk mengetahui perbedaan antar perlakuan.

\section{HASIL DAN PEMBAHASAN}

Tingat intensitas cahaya selama penelitian, sejak pagi sampai sore tidak mengalami perubahan dikarenakan sumber cahaya hanya berasal dari lampu LED itu sendiri. Pada perlakuan LED grow light 100 watt mencapai 3490 lux, perlakuan LED grow light 200 watt sebesar 4850 lux, perlakuan LED grow light 300 watt dengan intensitas cahaya 5330 lux, perlakuan LED warna putih 300 watt sebesar 7890 lux perlakuan LED warna putih 200 watt sebesar 4460 lux, dan perlakuan LED warna putih 100 watt sebesar 3240 lux.

Berdasarkan pengukuran intensitas cahaya mengunakan lux meter, intensitas cahaya LED dengan cahaya grow light tertinggi diperoleh pada perlakuan 300 watt grow light, dimana perlakuan ini menggunakan lampu dengan daya 300 watt sehingga cahaya yang dihasilkan lebih tinggi dibandingkan dengan perlakuan 100 watt grow light dan 200 watt grow light. Pada perlaluak intensitas cahaya LED dengan cahaya putih, tingkat intensitas cahaya tertinggi pada perlakuan 300 watt putih, dimana pada perlakuan ini mengunakan lampu dengan listrik 300 watt, sehingga menghasilkan intensitas cahaya yang lebih tinggi dibandingkan dengan perlakuan 200 watt putih dan 100 watt putih. Suhu dan kelembapan pada ruang gelap pada pagi hari antara mencapai $19,8-25,4^{\circ} \mathrm{C}$ dengan RH 47 - 49\% pada siang hari suhu mencapai 28,6-30.50C dengan RH37-41\%, sore hari suhu mencapai 27,5-28,80C dengan RH $34-39 \%$.

Berdasarkan hasil uji sidik ragam, tingkat intensitas cahaya berpengaruh sangat nyata terhadap jumlah daun dan diameter tajuk. Semakin tinggi tingkat intensitas cahaya maka pertumbuhan tanaman akan semakin optimal sehingga memberikan hasil hasil terbaik pada variabel diameter jatuk dan jumlah daun (Haryadi dan Denis. 2017).

Tabel 1 Parameter pertumbuhan

\begin{tabular}{ccc}
\hline Perlakuan & Diameter Tajuk & Jumlah Daun \\
\hline 100w grow light & $37,30(\mathrm{C})$ & $10,00(\mathrm{C})$ \\
200w grow light & $41,90(\mathrm{AB})$ & $13,25(\mathrm{~B})$ \\
300w grow light & $45,10(\mathrm{~A})$ & $18,25(\mathrm{~A})$ \\
300w putih & $43,70(\mathrm{~A})$ & $17,25(\mathrm{~A})$ \\
200w putih & $39,20(\mathrm{~B})$ & $10,75(\mathrm{C})$ \\
100w putih & $30,70(\mathrm{D})$ & $9,50(\mathrm{C})$ \\
\hline KV(\%) & 3,81 & 6,10 \\
\hline
\end{tabular}

\section{Diameter Tajuk}

Diameter tajuk merupakan parameter penting dalam budidaya tanaman selada, dimana semakin lebar diameter tajuk maka luas daun semakin luas, sehingga menghasilkan hasil panen yang tinggi pula. Diameter tajuk diukur tiga hari sekali mulai pindah tanam, diukur pada tajuk terlebar. 


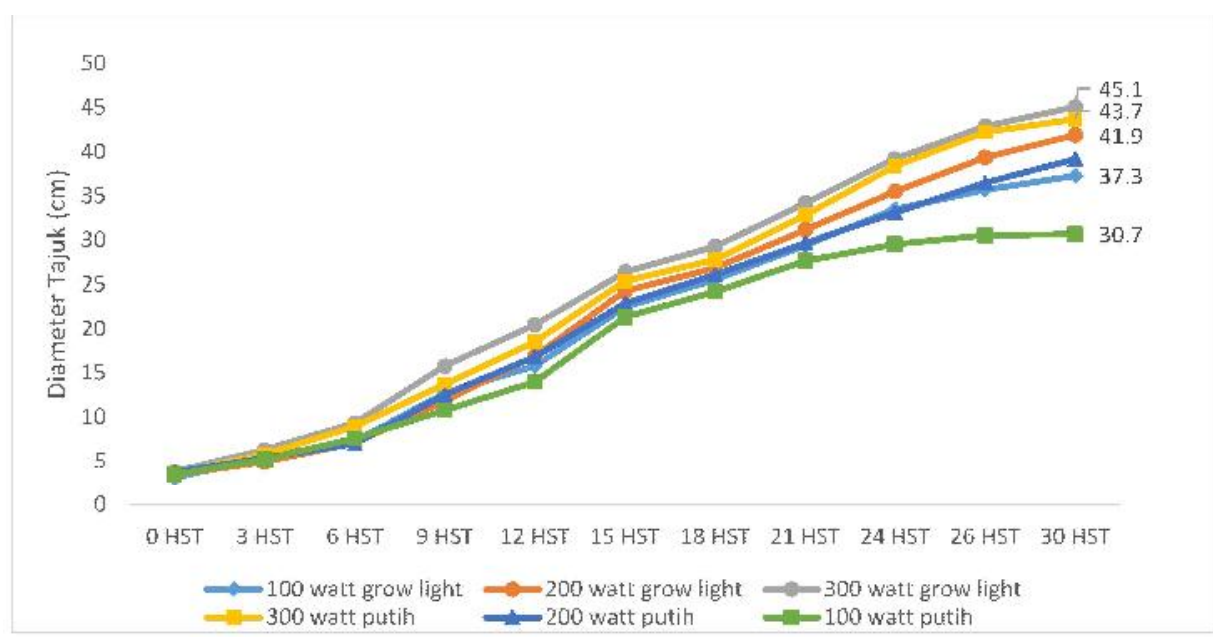

Gambar 1 Grafik diameter tajuk, dilakukan pengukuran tiga hari sekali

Dari hasil penelitian pada Gambar 1, dimana hasil pengukuran diameter tajuk setiap tiga hari sekali mengalami kenaikan dari awal pindah tanam sampi dengan panen, pada perlakuan 300 watt grow light dan perlakuan 300w putih tidak berbeda nyata, akan tetapi berbeda nyata dengan perlakuan 200 watt grow light, 200 watt putih, 100 watt grow light dan 100 watt putih. Pada perlakuan 300 watt grow light mem-peroleh hasil diameter tajuk tertinggi sebesar 45,1 cm, dimana semakin luas diameter tajuk maka cahaya yang ditangkap semakin besar pula, pada perlakuan 300 watt grow light tanaman selada memperoleh intensitas cahaya yang cukup serta warna cahaya perpaduan antara warna merah dengan warna biru yang menyebabkan tanaman selada mengalami pertumbuhan lebih baik dibandingkan dengan perlakuan warna cahya putih. Dimana pada pelakuan 300 watt grow light mengunakan lampu 300 watt dengan warna cahaya grow light. Cahaya grow light dapat mempercepat proses fotosintesis pada tanaman. Cahaya dengan warna biru dan merah baik untuk pertumbuhan tanaman dikarenakan klorofil menyerap cahaya biru dan merah sehingga fotosintesis berjalan dengan optimal dibandingkan dengan cahaya lain (Syafriyudin, 2015). Cahaya biru digunakan tanaman untuk pada fase vegetatif dan cahaya merah digunakn tanaman pada fase generatif. (Soeleman dan Rahayu, 2013).

Perlakuan 100 watt putih memperoleh hasil diameter tajuk terkecil sebesar $30,70 \mathrm{~cm}$ dimana pada perlakuan ini tanaman mengalami etiolasi. Etiolasi ditunjukan dengan bentuk daun yang sempit serta batang tanaman selada yang memanjang. Diamana pada perlakuan 100 watt putih, menggukana lampu LED dengan daya 100 watt sehingga intesitas cahaya yang dihasilkan cukup rendah dan tidak dapat memenuhi kebutuhan cahaya yang dibutuhkan oleh tanaman.

\section{Jumlah Daun}

Jumlah daun merupakan parameter penting dalam budidaya tanaman selada, dimana tanaman selada yang dapat dikonsumsi bagian daun saja, semakin banyak jumlah daun maka pertumbuhan tanaman semakin maksimal. 


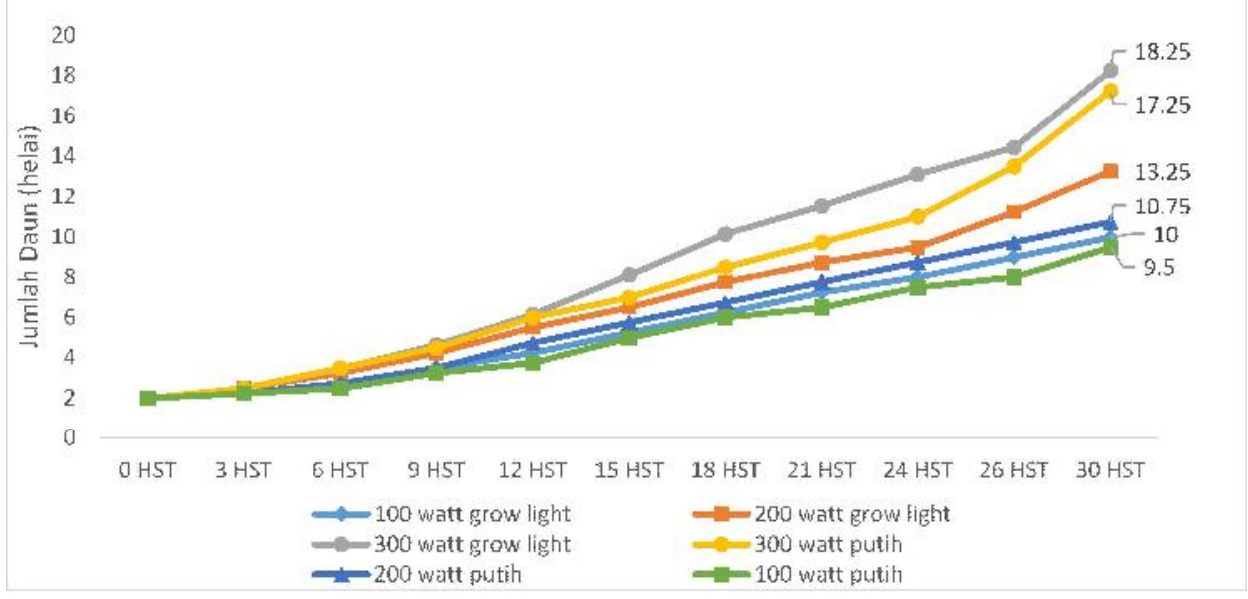

Gambar 2 Grafik jumlah daun yang diamati 3 hari sekali

Berdasarkan Gambar 2, pada perlakuan 300 watt grow light dan 300 watt putih tidak berbeda nyata, akan tetapi berbedanya dengan perlakuan yang lain, dimana pada perlakuan 300 watt grow light memiliki jumlah daun terbanyak dengan rata-rata daun sejumlah 18,25 helai, dimana pada perlakuan ini mengunakan lampu LED 300 watt. Pada pelakuan 300 watt grow light tanaman memperoleh cahaya yang cukup dan warna cahaya peraduan antara cahaya ungu dan merah, berdasarkan penelitian Mikrajuddin (2017) dimana pada tanaman yang ditanam pada cahaya merah dan ungu membuat tanaman mengalami pertumbuhan tanaman yang lebih cepat dan jumlah daun semakin banyak, sehingga pertumbuhan tanaman dapat tumbuh maksimal dan tanaman tidak mengalami etiolasi, dengan ditunjukan batang daun yang pendek dan jarak atar ruas daun sangatlah rapat serta daun yang lebih lebar dibandingakan dengan perkaluan yang lain.

Perlakuan 100 watt grow light memperoleh hasil jumlah daun terendah sebanyak 9,5 helai, pada pelakuan 100 watt grow light tanaman mengalami kekurangan intensitas cahaya, yang menyebabkan tanaman mengalami etiolasi sehingga tanaman tidak dapat tumbuh secara maksimal. Dimana cahaya berperan penting untuk mendukung proses fotosintesis tanaman. Menurut Pertamawati (2010), Proses fotosintesis akan optimal apabila daun yang menjadi tempat berlangsungnya proses fotosintesis memiliki jumlah daun yang banyak, dimana semakin banyak jumlah daun serta memiliki luas daun yang besar, dapat menangkap cahaya lebih tinggi sehingga pertumbuhan tanaman dapat tumbuh maksimal. Baur et al. (2014) berpendapat jumlah daun akan mempengaruhi perkembangan tanaman, dimana semakin banyak jumlah daun maka semakin banyak cahaya yang ditangkap pula sehingga prosesfotosintesis meningkat.

\section{Parameter Hasil Panen}

Tanaman selada dapat dipanen pada umur 30 hari setelah pindah tanaman. Berdasarkan hasil uji lanjut BNJ menggunakan taraf nyata 5\%, pada parameter berat berangkasan basah tajuk, berat berangkasan basah akar perlakuan 300 
watt grow light menunjukkan hasil terbaik, dibandingkan dengan parameter yang lain.

\section{Berat Berangkasan Basah Tajuk}

Parameter berat berangkasan basah tajuk merupakan parameter penting dimana semakin berat berangkasan basah tajuk maka hasil panen yang diperoleh semakin tinggi pula. terhadap berat berangkasan basah tajuk, dimana semakin tinggi tingkat intensitas cahaya maka proses fotosintesis akan lebih cepat. Hasil fotosintesis akan ditranslokasikan keseluruh jaringan tanaman melalui floem, yang selanjutnya energi hasil fotosintesis akan dipergunakan tanaman untuk menunjang pertumbuhan tunas, daun, dan batang sehingga tanaman dapat

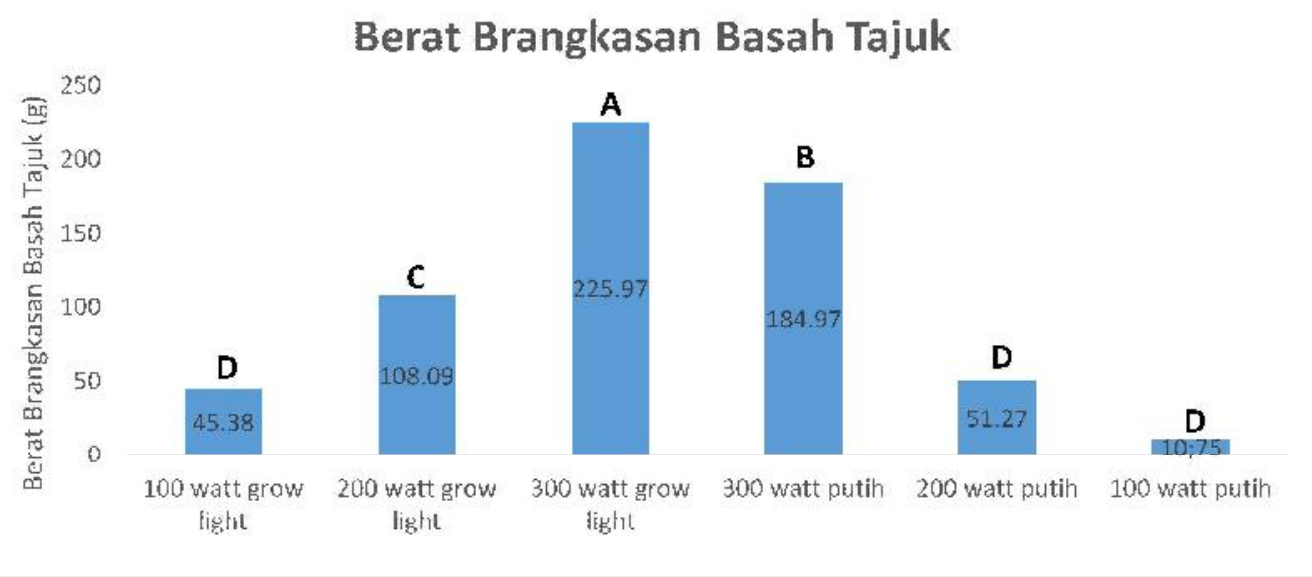

Gambar 3 Grafik Berat Brangkasan Basah Tajuk

Berdasarkan Gambar 3, pada perlakuan 300 watt grow light berbedanya nyata dengan perlakuan yang lainnya, dimana perlakuan 300 watt grow light memperoleh hasil terbaik diban-dingkan dengan perlakuan 300 watt grow light, 200 watt grow light, 200w putih, 100 watt grow light dan 100 watt putih, dengan hasil rata-rata sebesar 225,977 g, pada perlakuan 100 watt putih menunjukan hasil terendah dengan hasil rata-rata sebesar $10,75 \mathrm{~g}$. Sari et al., (2015) berpendapat penurunan berat segar berkaitan dengan diameter tajuk, jumlah daun, luas daun dan panjang akar, semakin kecil diameter tajuk dan semakin sedikit jumlah daun makan berat yang diperoleh akan kecil pula. Berdasarkan penelitian Susilowati, (2015) menyatakan bahwa semakin besar tingkat intensitas cahaya berpengaruh tumbuh optimal (Komala, 2017). Semakin besar daya listrik yang dibutuhkan oleh lampu LED maka intesitas yang dihasilkan oleh lampu LED akan semakin besar pula.

Pada perlakuan 300 watt grow light menggunakan 300 watt, dengan cahaya lampu LED grow light, dimana cahaya lampu LED grow light merupakan perpaduan antara cahaya berwarna merah dan biru. Cahaya yang dibutuhkan oleh tanaman untuk proses fotosintesin yaitu cahaya merah dan biru. sehingga tanaman pada perlakuan cahaya grow light dapat tumbuh dengan maksimal dibandingkan lampu LED dengan warna cahaya putih. Cahaya yang bersumber dari sinar matahari tidak semua digunakan oleh tanaman untuk proses fotosintesis. Hal ini disebut sebagai 
Photosynthetically Active Radiation (PAR) dengan rentang panjang gelombang kisaran (400-700) nm tergolong kedalam spektrum cahaya tampak (380-770) nm, dimana cahaya tampak dapat terlihat oleh mata manusia. Berdasarkan penelitan Sulistyaningsih et al., (2015) pemberian warna cahaya merah dan biru memberikan hasil terbaik pada parameter berat berangkasan basah tajuk pada tanaman caisin usia empat minggu setelah pindah tanaman mencapai $192 \mathrm{~g}$ dibandingkan dengan perlakuan yang lain.

\section{Berat Brangkasan Basah Akar}

semakin besar pula dimana pada pelakuan 300 watt grow light dan P3P lampu menggunakan daya 300 watt dengan intensitas cahaya pada perkaluan 300w grow light sebesar 5132,5 lux dan pada perakuan P3P intensitas cahaya sebesar 8347,5 lux.

Intensitas cahya yang dihasilkan dari cahaya lampu LED berpengaruh terhadap pertumbuhan tanaman, dimana semakin tinggi tingkat intesitas cahaya maka pertumbuhan tanaman dapat tumbuh secara optimal. Berdasarkan penelitian Susilowati (2015), semakin tinggi tingkat intesitas cahaya yang dihasilkan oleh

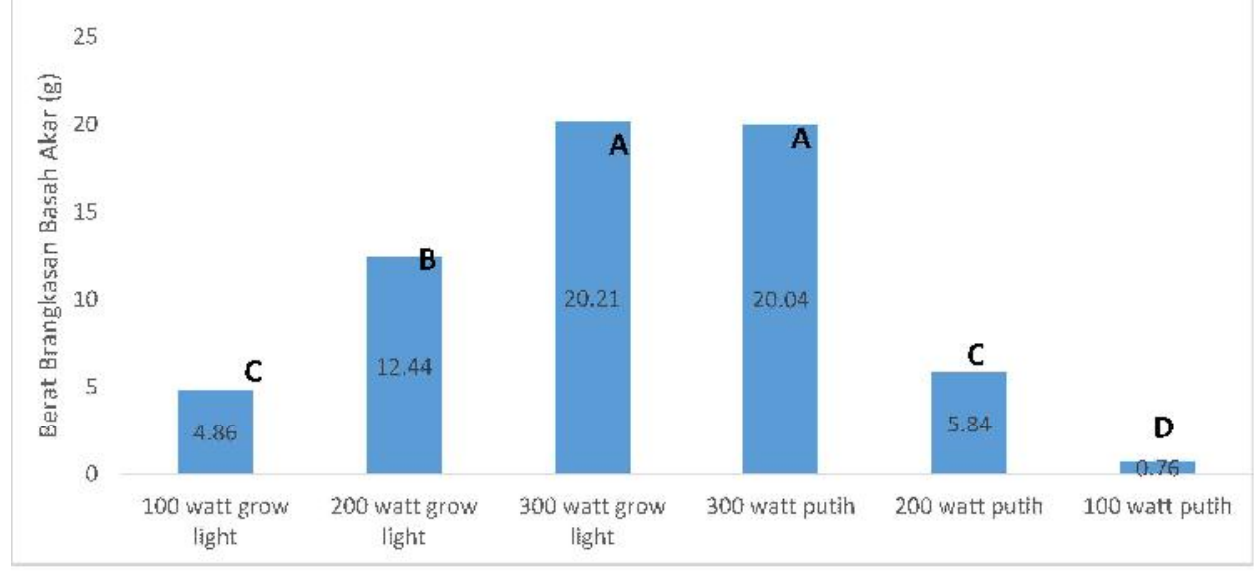

Gambar 4 Grafik Berat Brangkasan Basah Akar

Bedasarkan hasil penelitian berat berangkasan basah akar pada gambar 4, Berat berangkasan basah akar tertinggi pada perlakuan 300 watt grow light sebesar 20,21 g. Perlakuan 300 watt grow light dan perlakuan 300 watt putih tidak berbeda nyata dimana pada perlaku ini selisih berat berangkasan basah akar hanya sebesar 0,16 g, akan tetapi berbeda nyata dengan perlakuan 200 watt grow light, 200 watt putih, 100 watt grow light dan 100 watt putih. Semakin besar lampu yang diberikan makan intesitas cahaya yang dihasilkan akan lampu LED maka berat berangkasan akar yang dihasilkan sekamin tinggi pula. Menurut Hasan (1987) menyatan bahwa tingkat intesitas cahaya yang diperoleh tanaman mempengaruhi serapan hara tanaman.

\section{Berat Brangkasan Kering Tajuk}

Pada hasil parameter berat berangkasan kering tajuk pada perlakuan 300 watt grow light berbeda nyata terhadap perlakuan yang lain, dimana pada perlakuan 300 watt grow light memperoleh hasil terbaik dibandingan dengan 


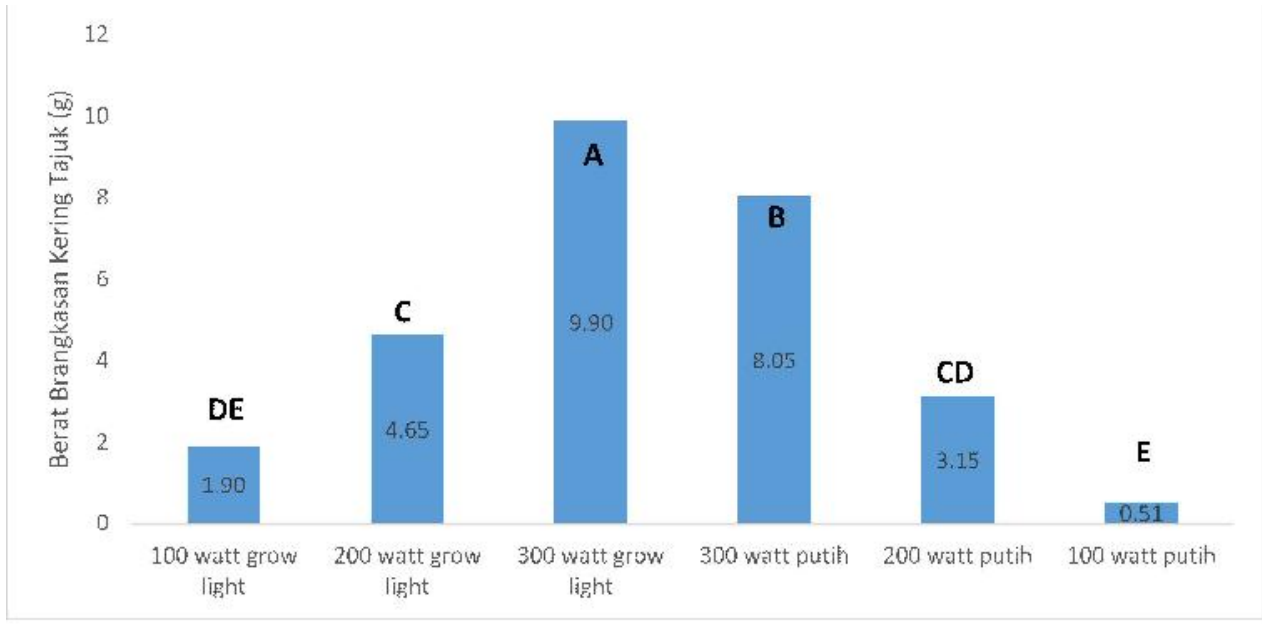

Gambar 5 Grafik Berat Brangkasan Kering Tajuk

perlakuan yang lain, dengan berat berangkasan kering tajuk mencapai 9,90 g. Dimana pada perlakuan 300 watt grow light menggunakan lampu LED dengan daya lampu 300 watt dengan warna cahaya grow light seingga pertumbuhan tanaman dapat tumbuh dengan maksimal. Pada perlakuan 100 watt putih, tanaman memperoleh intensitas cahaya rendah yang mengakibatkan pertumbuhan tidak dapat tumbuh dengan maksimal.
Berat kering dapat diperoleh dengan maksimal jika tanaman mendapatkan intensitas cahaya penuh (Lindawati 2015). Berat kering dari hasil panen yang diperoleh merupakan hasil peningkatan asimilasi $\mathrm{CO} 2$ bersih selama terjadinya pertumbuhan vegetatif tanaman (Perwitasari, 2012)

\section{Berat Brangkasan Kering Akar}

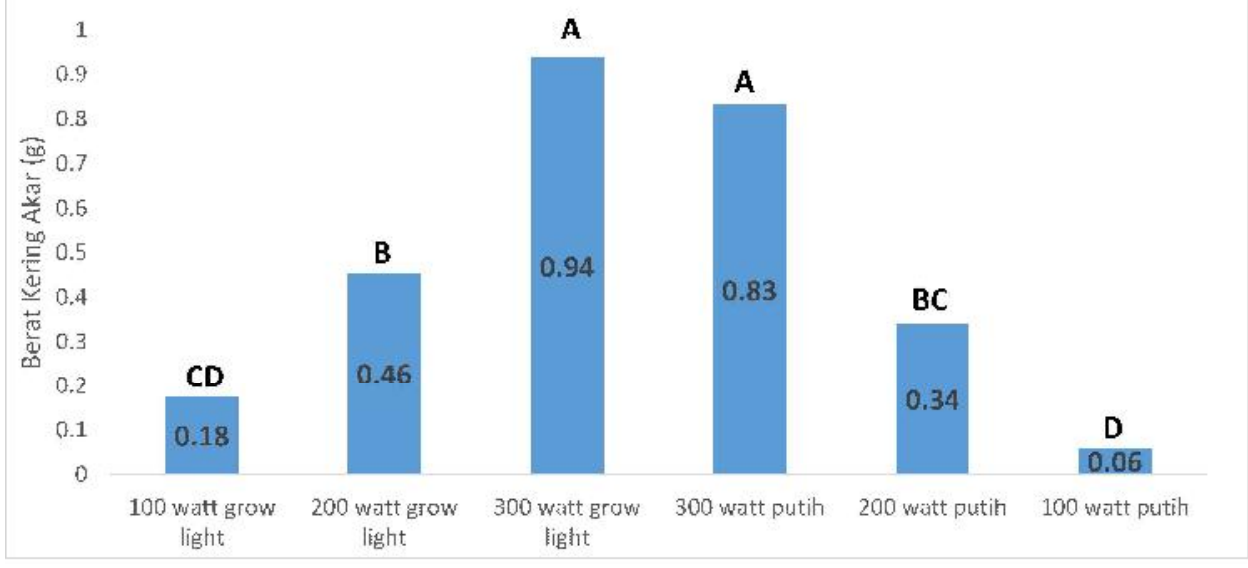

Gambar 6 Grafik Berat Brangkasan Kering Akar 
Berdasarkan Gambar 6 hasil terbaik berat brangkasan kering akar pada perlakuan 300 watt grow light. Pelakuan 300 watt grow light dan 300w putih tidak berbeda nyata melainkan berbeda nyata terhadap perlakuan 200 watt grow light, 200 watt putih, 100 watt grow light dan 100 watt putih dimana pada perlakuan 100 watt putih tanaman memperoleh intensitas cahaya rendah yang mengakibatkan pertumbuhan tanaman tidak dapat tumbuh dengan maksimal. Berdasarkan hasil penelitian dari parameter berat brangkasan basah tajuk, berat berangkasan basah akar, berat brangkasan kering tajuk, jumlah daun dan diameter tajuk menunjukan bahwa perlakuan 300w grow light merupakan perlakuan yang terbaik.

\section{Kadar Klorofil}

Untuk mengetahui kandungan klorofil pada tanaman selada dapat dilihat pada Tabel 2 .

Berdasarkan hasil penelitian bahwa kadar klorofil a, klorofil b dan total klorofil pada tanaman selada antar semua perlakuan tidak berbeda nyata. Menurut Sayekti et al., (2017) kandungan klorofil dipengaruhi oleh intensitas cahaya, dimana intensitas cahaya memiliki peranan penting dalam proses fotosintesis, klofofil berhubungan dengan jumlah energi yang diterima untuk melakukan proses fotosintesis. Kandungan klorofil pada perlakuan spekrtum cahaya merah dan biru tidak berbeda nyata dengan spektrum cahaya warna putih, meskipun kandungan klorofil tertinggi pada didapat pada perlakuan pemberian cahaya warna merah (Wicaksono, 2014). Nilai tertinggi yaitu pada perlakuan 100 watt putih dengan dengan parameter klorofil a dan total klofil. Dimana pada perlakuan klorfil b nilai tertinggi pada perlakuan 200 watt grow light dimana daya lampu dan warna cahaya tidak mempengaruhi terhadap pertumbuhan tanaman selada meskipun pada perlakuan 100 watt putih memperoleh hasil tertinggi.

\section{Luas Daun}

Untuk mengetahui rata-rata luas daun pada tanaman selada dapat dilihat pada Gambar 7.

Berdasarkan Gambar 7, dapat dilihat luas daun tanaman selada tertinggi yaitu pada perlakuan 300 watt grow light dengan nilai rata-rata $6195,38 \mathrm{~cm}^{2}$, dimana pada perlakuan $300 \mathrm{watt}$ grow light berbeda nyata terhap perlakuan yang lain. Luas daun tanaman salada terendah yaitu pada perlakuan 100 watt putih dengan

Tabel 2 Rata-Rata Kandungan Klorofil A, Klorofil B dan total klorofil pada Tanaman Selada $(\mu \mathrm{g} / \mathrm{ml})$

\begin{tabular}{cccc}
\hline Perlakuan & klorofil A & klorofil B & total klorofil \\
\hline 100w grow light & $4,605(\mathrm{~A})$ & $1,765(\mathrm{~A})$ & $6,362(\mathrm{~A})$ \\
200w grow light & $4,164(\mathrm{~A})$ & $2,064(\mathrm{~A})$ & $6,228(\mathrm{~A})$ \\
300w grow light & 4,899 (A) & $1,221(\mathrm{~A})$ & $6,247(\mathrm{~A})$ \\
300w putih & $5,231(\mathrm{~A})$ & $1,470(\mathrm{~A})$ & $6,701(\mathrm{~A})$ \\
200w putih & $5,482(\mathrm{~A})$ & $1,642(\mathrm{~A})$ & $7,125(\mathrm{~A})$ \\
100w putih & $5,563(\mathrm{~A})$ & $1,704(\mathrm{~A})$ & $7,268(\mathrm{~A})$ \\
\hline KV (\%) & 20.89 & 21.34 & 17.23 \\
\hline
\end{tabular}




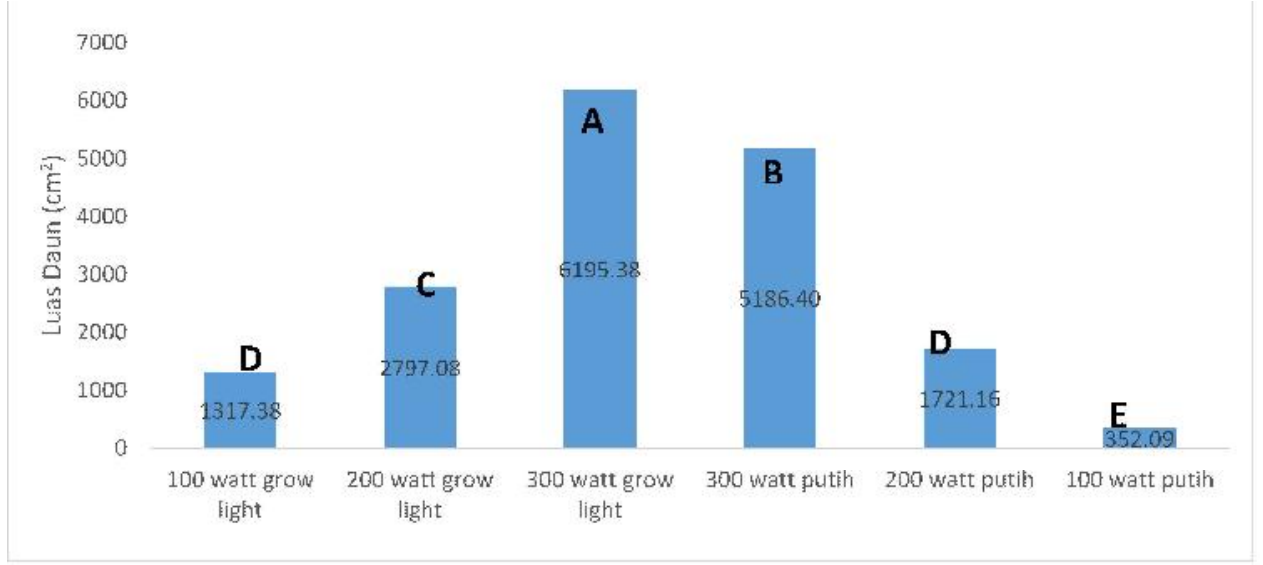

Gambar 7 Rata-Rata Luas Daun Tanaman Selada $\left(\mathrm{cm}^{2}\right)$

nilai rata-rata $352.09 \mathrm{~cm}^{2}$, dimana pada perlakuan 100 watt putih menggukan daya lampu 100 watt dengan warna cahaya putih, sehingga cahaya yang dikeluarkan dari lampu LED sangat rendah dan tidak dapat memenuhi kebutuhan intesitas cahaya tanaman selada yang mengakibatkan pertumbuhan tanaman tidak dapat tumbuh secara optimal dengan. Semakin tinggi tingkat intensitas cahaya maka luas daun yang di hasilkan semakin tinggi pula, dimana pada perlakuan dengan tingkat intesitas cahaya 8830 lux memperoleh hasil luas daun terlebar dibandingkan dengan perlakuan lain (Nurdianna et ol., 2018). Widiastuti et al., (2004) menyatakan bahwa rendahnya intensitas cahaya menyebabkan pertumbuhan tanaman terhambat,sehingga luas daun menjadi sempit. Penurunan jumlah daun yang terbentuk juga menurunkan luas daun, karena laju fotosintesis ikut menurun. Pada perlakuan 300 watt dengan cahaya lampu LED grow light, sehingga tanaman dapat tumbuh dengan optimal, dan menghasilkan luas daun tanaman selada dengan jumlah luas pula dibandingkan lampu LED dengan warna putih.
Korelasi Sumber Cahaya dan Lama Penyinaran Terhadap Pertumbuhan Tanaman Selada

Tabel 3 Nilai Korelasi Antar Parameter Pertumbuhan

\begin{tabular}{|c|c|c|c|c|c|c|c|c|c|c|}
\hline & DT & JD & BBT & BBA & BKT & BKA & LD & TK & KA & $\mathrm{KB}$ \\
\hline DT & 1 & 0,849 & 0,895 & 0,910 & 0,910 & 0,910 & 0,897 & $-0,617$ & $-0,173$ & $-0,385$ \\
\hline JD & & 1 & 0,991 & 0,981 & 0,976 & 0,972 & 0,986 & $-0,466$ & 0,078 & $-0,614$ \\
\hline BBT & & & 1 & 0,985 & 0,995 & 0,989 & 0,998 & $-0,429$ & 0,082 & $-0,627$ \\
\hline BBA & & & & 1 & 0,979 & 0,985 & 0,982 & $-0,507$ & $-0,010$ & $-0,527$ \\
\hline BKT & & & & & 1 & 0,997 & 0,998 & $-0,429$ & 0,132 & $-0,651$ \\
\hline BKA & & & & & & 1 & 0,995 & $-0,393$ & 0,148 & $-0,648$ \\
\hline LD & & & & & & & 1 & $-0,441$ & 0,127 & $-0,662$ \\
\hline TK & & & & & & & & 1 & 0,652 & $-0,015$ \\
\hline $\mathrm{KA}$ & & & & & & & & & 1 & $-0,748$ \\
\hline $\mathrm{KB}$ & & & & & & & & & & 1 \\
\hline
\end{tabular}

Keterangan: (DK: diameter Tajuk; JD: jumlah daun; BBT: berat basah tajuk; BBA: berat basah akar; BKT: berat kering tajuk; BKA: berat kering akar;TK: total klorofil; KA: klorofil a; KB: klorofil b)

Tabel 3 menunjukkan nilai korelasi antar parameter pertumbuhan yang telah diamati pada subbab sebelumnya. Berdasarkan hasil analisis statistik menggunakan uji korelasi, parameter jumlah daun memiliki korelasi sangat kuat secara signifikan (Sig. 2-tailed value $<0.05)$ dengan parameter diameter krop pada nilai korelasi sebesar 0.849 (> r tabel 0.4044). Diameter krop dalam hal ini sangat dipengaruhi oleh jumlah daun dimana daun adalah penyusun dari krop tanaman B. juncea sehingga semakin 
tinggi nilaijumlah daun akan semakin tinggi pula nilai diameter kropnya. Nilai korelasi seperti ini identik pada tanaman sayuran yang daunnya membentuk krop. Sebagai contoh, Murniati dkk. (2013) tidak menemukan korelasi kuat antara jumlah daun dengan diameter tajuk pada tanaman C. annuum.

Parameter jumlah daun juga memiliki korelasi sangat kuat secara signifikan (Sig. 2-tailed value $<0.05$ ) dengan berat basah tajuk pada nilai korelasi sebesar 0.991 (> r tabel 0.4044) dan dan berat kering tajuk pada nilai korelasi sebesar 0.976 (> r tabel 0.4044). Hubungan erat ini dapat dimengerti mengingat organ daun pada tanaman B. juncea adalah penyusun dari sebagian besar tajuknya. Semakin tinggi jumlah daun akan semakin tinggi pula berat basah dan berat keringnya, semakin rendah jumlah daun akan semakin rendah pula berat basah dan berat keringnya.

Parameter berat basah akar dan berat kering akar juga memiliki korelasi secara signifikan (Sig. 2-tailed value >0.05) dengan parameter jumlah daun, masing-masing pada nilai korelasi 0.981 dan 0.972 (> r tabel 0.4044). Organ akar berperan dalam proses penyerapan nutrisi atau unsur hara pada media hidroponik yang digunakan. Menurut pendapat Permanasari et al. (2014), pembentukan akar secara baik akan memberikan konstribusi yang sangat baik pula dalam proses organ lain. Dengan demikian, semakin berkembang akar tanaman B. juncea akan berdampak pula pada semakin meningkatnya penyerapan unsur hara. Secara langsung, unsur hara ini akan digunakan oleh B. juncea untuk pembentukan daun. Dapat disimpulkan bahwa semakin tinggi nilai berat basah akar dan berat kering akar akan semakin meningkatkan jumlah daun berhasil dibentuk oleh B. juncea. Hasil serupa juga ditemukan oleh Budihastuti (2017) dan Surtinah (2017) bahwa ada hubungan antara biomassa akar dengan jumlah daun yang dihasilkan pada tanaman A. marina dan jumlah biji pada tanaman G. max L. Merill.

Dalam penelitian ini, nilai jumlah total klorofil tidak memiliki korelasi secara signifikan (Sig. 2-tailed value >0.05) dengan parameter diameter krop, jumlah daun, berat basah tajuk, berat basah akar, berat kering tajuk, dan berat kering akar. Hal ini disebabkan karena pembentukan klorofil berkaitan dengan respon pembentukan fisiologis dari tanaman B. juncea, sedangkan keenam parameter tersebut lebih berkaitan dengan respon pembentukan morfologis. Dengan demikian tidak ada hubungan antara total klorofil dengan parameter yang lainnya.

\section{KESIMPULAN}

Berdasarkan hasil penelitian ini dapat disimpulkan bahwa perlakuan pemberian lampu LED serta pemberian cahaya grow light dapat mempengaruhi pertumbuhan tanaman selada, dimana pada perlakuan 300 watt grow light dan 300 watt putih memberikan hasil terbaik yang berbeda nyata dengan perlakaun yang lain, tetapi memberikan hasil terbaik dibandingkan dengan perlakuan yang lain. Dimana semakin tinggi daya lampu yang dibutuhkan makan pertumbuhan tanaman selada akan sakin baik pula. Pada penelitian ini lampu LED 300 watt dengan warna cahaya grow light memberikan hasil terbaik pada pada parameter berat berangkasan basah tajuk, berat berangkasan kering tajuk, luas daun. 
Pengaruh Variasi Sumber Cahaya LED Terhadap Pertumbuhan dan Hasil Tanaman Selada dengan Sistem Budidaya Hidroponik Rakit Apung (Antonius Novinanto dan Andree Wijaya Setiawan)

\section{DAFTAR PUSTAKA}

Badan Pusat Statistik. 2018. luasan lahan $\mathrm{p}$ e r t a n i a n . ht $\mathrm{p} \mathrm{s}: / /$ webcache.Googleusercontent .com/ search?q=cache:m3fMfWpyM5kJ:https:/ /economy.okezone.com/read/2018/10/ 30/320/1970900/bps-luas-lahanp e r t a n i a n - s e makinmenurun+\&cd=5\&hl=id\&ct=clnk\&gl=id. Diaksen 29 januari 2018 jam 22,17 WIB.

Badan Pusat Statistika. 2013. Statistik Produksi Hortikultura Tahun 2013. Kementerian Pertanian: Jakarta.

Baur, S., Klaiber, R. G., Koblo, A., \& Carle, R. 2004. Effect of different washing procedureson phenolic metabolism of shredded, packaged iceberg lettuce during storage. Jurnal of agricultural and food chemistry Vol 52 (23); 7017-7025

Budihastuti R. 2017. Hubungan antara tinggi tegakan, biomasa akar dan jumlah daun semai mangrove Avicennia marina. Buletin Anatomi dan Fisiologi 2(1):31-36.

Haryadi Rudi, Denis Saputra. 2017. Pengaruh Cahaya Lampu 15 Watt Terhadap Pertumbuhan Tanaman Pandan (Pandanus Amaryllifolius). Jurnal untirta vol 3 no 2 (100-109)

Hasan Zulkifli.1987. Serapan Hara Bibit Tanaman Cengkeh Pada Berbagai Naunan dan Zat Pengatur Tumbuh Mix Talol. Jurnal Bul. Littro. Vo 11 (20: 41-52).

Komala Dyah Fajar 2017. Otomatisasi Pengendalian Pencahayaan Untuk Tanaman Selada (Lactuca Sativa L.)
Dengan Sistem Tanam Hidroponik Di Dalam Greenhouse. Skripsi. Program Studi Fisika Jurusan Pendidikan Fisika Fakultas Matematika dan Ilmu Pengetahuan Alam Universitas Negeri Yogyakarta.

Limantara, L., dan Heriyanto. 2010. Studi Komposisi Pigmen dan Kandungan Fukosantin RumputLaut Coklat dari Perairan Madura dengan Kromatografi Cair Kinerja Tinggi. Jurnal Ilmu Kelautan,15(1): 23-32.

Mikrajuddin Abdulah. 2017. Keefektifan Spektrum Cahaya Terhadap Pertumbuhan Tanaman Kacang Hijau. Jurnal Ilmiah Penelitian dan Pembelajaran Fisika, Vol 4, No.2, Hal 93-102

Nurdianna Daru., Retno Bandriyati Arni Putri., Dwi Harjoko.2018. Penggunaan Beberapa Komposisi Spektrum Led Pada Potensi dan Hasil Hidroponik Indoor Selada Keriting Hijau. Jurnal Agrosains. Vol 20(1): 1-6

Pertamawati. 2010. Pengaruh Fotosintesis Terhadap Pertumbuhan Tanaman Kentang (Solanium Tuberosum L.) dalam Lingkungan Fotoautrotrof Secara Invitro. Jurnal Sains dan Teknologi Indonesia. 12(1): 31-37.

Restiani AR, Triyono S, Tusi A, Zahab R. 2015. Pengaruh jenis lampu terhadap pertumbuhan dan hasil produksi tanaman selada (Lactuca sativa L.) dalam sistem hidroponik indoor. Jurnal teknik pertanian Lampung. 4 (3): 219 226.

Sari, D. N. I., Daningsih, dan Mardiyaningsih A.N. 2015. Perbedaan Konsentrasi 
Gandasil B Terhadap Pertumbuhan

Selada Pada Hidroponik Mini. Jurnal

Pendidikan dan Pembelajaran, 4 (12)

Sayekti Sundari Esti Harpeni, dan Moh.

Muhaemin. 2015. Pengaruh Intensitas

Cahaya Terhadap Kandungan klorofil-

A dan -C Zooxanthellae Dari Isolat

Karang Lunak Zoanthus sp. Jurnal maspari 9(1):61-68

Soeleman, S dan D. Rahayu. 2013. Halaman

Organik: Mengubah Taman Rumah

Menjadi Taman Sayuran Organik

Untuk Gaya Hidup Sehat. PT Agro

Media Pustaka. Jakarta Selatan.

Sutiyoso, Y. 2006. Hidroponik

Sugara Kosmas. 2012 Budidaya Selada

Keriting, Selada Lollo Rossa, dan

Selada Romaine Secara Aeroponik Di

Amazing Farm, Lembang, Bandung.

Skripsi. Fakultas Pertanian Institut

Pertanian Bogor.

Sugara, K. 2012. Budidaya Selada Keriting,

Selada Lollo Rossa, dan Selada

Romane Secara Aeroponik di Amazing

Farm, Lembang, Bandung. Skripsi.

Departemen Agronomi dan Hortikultura.

Fakultas Pertanian Institut Pertanian

Bogor.

Sulistyaningsih Endang dkk. 2015.

Pertumbuhan dan Hasil Caisin Pada

Berbagai Warna Sungkup Plastik.

Jurnal ilmu pertanian. Vol 12(1) 65-76
Surtinah. 2017. Korelasi pertumbuhan organ vegetatif dengan produksi kedelai (Glycine max (L) Merill). Seminar Nasional "Mitigasi dan Strategi Adaptasi Dampak Perubahan Iklim Di Indonesia".

Susilowati Eka, dkk. 2015. Pengaruh Jarak Lampu Neon Terhadap Pertumbuhan Tanaman Kailan (Brassica Oleraceae) Dengan Sistem Hidroponik Sumbu di Dalam Ruangan. Jurnal Teknik Pertanian LampungVol. 4, No. 4: 293304.

Syafriyudin, N.T.L. 2015. Analisis Pertumbuhan Tanaman Krisan Pada Variabel Warna Cahaya Lampu LED. Jurnal. Teknologi. 8 (1): 83-87.

Wicaksono Gantheng. 2014. Pengaruh Pemberian Spektrum Cahaya Berbeda Terhadap Kandungan Klorofil Spirulina sp. Skripsi. Fakultas Perikanan dan Kelautan Universitas Airlangga.

Widiastuti, L., Tohari, dan E. Sulistyaningsih. 2004. Pengaruh Intensitas Cahaya dan Kadardaminosida Terhadap Iklim Mikro dan Pertumbuhan Tanaman Krisan Dalam Pot. Jurnal Ilmu Pertanian, vol 11 (2) : 35-42 